\title{
A Journal Editor's Identity Journey: An Autoethnography of Becoming, Being, and Beyond
}

\author{
Heewon Chang \\ Eastern University \\ U. S. A.
}

ABSTRACT: This autoethnography essay describes the identity journey of the founding editor-in-chief of the International Journal of Multicultural Education (IJME). In this essay the author shares her story of founding and becoming the editor of this international journal, the sociocultural meaning of being a journal editor to her, and her decision to leave this journal editor position. She frames the multicultural identity discourse in an autoethnographic narrative style and links her journal editor identity with the journal's identity focusing on justice, open-access, and peer-review.

KEYWORDS: editor identity, multicultural education, open-access, autoethnography, intersectionality

Autoethnography, Identity, and Multicultural Education Becoming

Being

Beyond

With Blessings to IJME Leaders and Followers

Acknowledgment

References

Author Contact

My journey as a journal editor has stretched over 20 years. When I founded the Electronic Magazine of Multicultural Education (EMME) in 1997 and became its editor, I was an eager novice who did not know where the journey would take me. After eight years of publication, I founded a new journal, International Journal of Multicultural Education (IJME), to replace EMME. While IJME has been flourishing for over 10 years with more advanced technology, an improved review process, and better outreach to the global community, I too have been settling and maturing as its founding Editor-in-Chief. These 20 combined years of journal editing have made an indelible mark on my personal and professional identity. It became natural for me to claim a journal editor identity; EMME and IJME also became known to the world through my editorship. Now things are about to change. After this issue, I will officially step down from the IJME Editor-in-Chief position, and the journal's editorial office will move from Eastern University in the United States to Yonsei University in South Korea to expand its global reach. As I am facing this monumental change for the journal and myself, I cannot help but reflect on what this interwoven identity between the journal and me has been and what untangling these identities may bring to each of us in the future. In this essay, I am 
adopting a methodological approach of autoethnography to discuss the personal, scholarly, and professional dimensions of my journal editor identity and to contextualize the identity discussion in a broader multicultural discourse as my journal editor identity interacts with other dimensions of my identity, such as gender, race, ethnicity, nationality, immigrant status, professional experience, language experience, and religion.

\section{Autoethnography, Identity, and Multicultural Education}

Autoethnography is rooted in the qualitative research orientations of ethnography and narrative inquiry. The story-telling nature of narrative inquiry and the cultural analysis of ethnographic emphasis mix in autoethnography when researchers examine their lived experience with a social phenomenon. When autoethnography initially appeared in anthropology, the disciplinary home of the ethnographic method, Hayano (1979) coined the term "autoethnography" to refer to the ethnography of the researcher's "own people" (p. 99). Later this label was applied to the ethnographic study of "self." The current development of autoethnography is indebted to the many early good works of Ellis and Bochner (1996), Reed-Danahay (1997), Ellis (2003), Denzin (2006), Andersen (2006), and many others whom I do not have enough space to mention here. The strong showing of autoethnographic works is evident in many methodological books and research journal articles. Some journals have dedicated a special issue to autoethnography: e.g., Journal of Contemporary Ethnography (Hunt \& Junco, 2006), Journal of Research Practice (Ngunjiri, Hernandez, \& Chang, 2010), Qualitative Health Research (2016), International Journal of Multicultural Education (Marx, Pennington, \& Chang, 2017), and Journal of Organizational Ethnography (Sambrook \& Herrmann, 2018). Autoethnography, whether conducted individually by a solo researcher or collaboratively by a group of researchers, is accepted as a uniquely contributing qualitative research method that engages researchers' autobiographic materials as primary data to gain broader understandings of social phenomena (Adams \& Jones, 2014; Chang, 2008; Chang, Ngunjiri, \& Hernandez, 2013; Jones, Adams, \& Ellis, 2013). Autoethnography now appears in the discipline of organizational leadership, into which I have expanded my scholarly interest (Hernandez, Ngunjiri, \& Chang, 2015). Although a variety of organizational leaders, such as a senior officer ("proctor") of Oxford University (Walford, 2004), leaders of color in U.S. higher education (Chang, Longman, \& Franco, 2014), women leaders in South African higher education (Mayer \& May, 2018), and an expected leader of a family-owned business (Yarborough \& Lowe, 2007), have published their autoethnographies, I have not encountered an autoethnography by a journal editor, particularly an organizational leader who has cared deeply about multicultural education. Thus I offer this essay to add to the literature of autoethnography in organizational leadership and multicultural education. I do not claim the essay as a full-fledged autoethnography because I have not undergone thorough and systematic autoethnographic data collection and analysis. Instead, I have relied primarily on fragmented memory data to construct this reflective interpretation of my lived experience. Despite its 
methodological limitations, however, I am allowing this modestly prepared essay to represent my autoethnographic work on my journal editor identity.

What is identity? Jenkins (2014) defined identity as "the human capacity rooted in language - to know 'who's who' (and hence 'what's what'). This involves knowing who we are, knowing who others are, them knowing who we are, us knowing who they think we are and so on" (p.6). This definition indicates that identity is a construct distinguishing one from others and defining the relative relationships with each other. From a socio-cultural perspective, identity is not only a demarcation tool to distinguish self from other individuals, but also a marker referring to an individual's attachment to groups as a member. Group membership can be ascribed by uncontrollable factors, such as birth, or achieved by intention and effort. As a member of a group, one's group identity or group affinity is typically formed and developed in an enculturation process of gaining cultural knowledge and competence specific to this group (Nesdale, 2017). As Jenkins pointed out, one's group identity is used and reinforced as an identification marker by others as well. In multicultural studies, many identity works, whether about self-identity or identity assigned by external members, have focused on ethnicity (Yoon, 2017), race (Way \& Rogers, 2015), language (Dervin \& Jackson, 2018), and gender (Litosseliti, 2006). In real life, one's identity is not singular because one belongs to many different cultural groups concurrently. Therefore, one's self-identity is inherently multicultural and multi-dimensional. Chang (2008) developed the concept of a "culture-gram" (pp. 97-100) to help users chart their multicultural and multidimensional identity as they belong to multiple groups by birth or choice, by implicit or explicit action, or by permanent or temporary affiliation. Also, according to the scholars of intersectionality, various dimensions of identity interact with each other (Crenshaw, 1991; Jones, Kim, \& Skendall, 2012; McClellen, 2012). The intersection of different identity dimensions produces individuals' different identity profiles and identity realities. For example, the intersectionality of race and gender will create different social experiences for White women and Black women (Dugger, 1988) and even differently for U.S.-born Black and immigrant Black women (Hernandez \& Murray-Johnson, 2015).

My journal editor identity is entwined with my professional commitment to multicultural education. That is to say, I not only created a journal focusing on matters of multicultural education but also espoused values advocated by the academic discipline of multicultural education. Multicultural education pursues educational equity for all while embracing cultural differences; this distinctive focus of multicultural education is unapologetically integrated into the scope of the journal. The mission of IJME is stated as "promoting educational equity for diverse students, cross-cultural understanding, and global justice for marginalized people in all levels of education, including leadership and policies" (International Journal of Multicultural Education, n.d.). However, this multicultural education vision-the foundation of my professional identity-does not remain separate from my personhood. It strongly resonates in the core of my identity because I am a "daughter of education." I grew up in Korea, a country that has valued education as a foundational building block of society as noted by James S. Gale, a Christian missionary and scholar from Canada to Korea in the late $19^{\text {th }}$ century $($ Yoo, 2012) 
and by contemporary education scholars (Kim, Lee, \& Lee, 2005; Sorenson, 1994). I was also raised by two education professors who believed in the power of education to bring the nation out of the legacies of colonial subjugation by Japan, post-war poverty and political unrest, and growing economic inequality in modern Korea. I am also a "child of justice and democracy." Having grown up in the era of political dictatorship in Korea during the 1970s and 1980s, I participated in justice work embedded in the democratic ideology and Christian vision of justice and equity. I am additionally an "immigrant woman of color" living in the United States. This minority status has been complicated by my ethnic, racial, and language majority status with educational and economic privilege before immigration; my heterosexual and racial privilege through a marriage to a European White male intellectual; and my professional privilege of a PhD-holding tenured professor. Korean-US-German trilingual and tricultural competence is the bedrock of my multicultural being as a person and professional. Thus I have built my journal editor identity upon my valuation of education, justice, and cultural multiplicity.

\section{Becoming}

The onset of my journal editor "identity journey" was not obvious; it began way before I actually became an editor. Ironically, my editor identity journey took off 35 years ago when I was excluded from being part of an editor group. In 1983 I was in my second year of the master's program in anthropology and education under the tutelage of the late Dr. Harry Wolcott, known for his scholarly excellence and exemplary mentorship. He was invited to edit Anthropology and Education Quarterly (AEQ), the flagship journal in my academic discipline. He invited his doctoral students to serve as his editorial assistants during his six-year tenure as AEQ's chief editor. Every year until I completed my doctoral dissertation in 1988, I secretly hoped that he would invite me to join the group of his editorial assistants. The invitation never came. In my head, I understood why I was not invited. As I was a non-native speaker of English, it is possible that he thought of me as a person to receive, not to offer, editorial assistance. Even though my head agreed with him, my heart refused to accept this logic. Despite his exclusion of me from this editorial arena, Dr. Wolcott mentored me well on other matters. He helped me to build my scholarly confidence in anthropology and education and affirmed my work in various ways. When my dissertation was completed, he nominated my work for two different dissertation awards, one for the American Anthropological Association (Council on Anthropology and Education) and the other for the American Educational Research Association. He also recommended my dissertation for publication; it was ultimately published as Adolescent Life and Ethos: An Ethnography of a US High School (Chang, 1992). In addition to boosting my scholarly confidence, he also imparted two enduring lessons. First, he demonstrated with his life that a successful White male professor, from a social elite background, can also suffer from stereotyping and discrimination due to his sexual orientation as a gay man. He never named this as a multicultural issue, but this multicultural issue of justice opened my eyes to a new reality of 
intersectionality. Second, he showed me that personal stories are worthy of scholarly examination as he wrote about this circumstance of prejudice and discrimination (Wolcott, 2002). Interestingly, he "refused" to label his personal story an "autoethnography"; instead he chose a new label, "ethnographic autobiography," for his work (Wolcott, 2004). Whatever he called it, the integration of life and scholarship, even in the face of professional vulnerability, resembles many efforts of autoethnography and Nash's (2004) "scholarly personal narrative." As I reflect on my professional engagement in multicultural education and autoethnography later in my career, I wonder if I am paying homage to his earlier intellectual influences. His mentorship beyond my dissertation work continued for over 30 years, until his passing in 2012, through the thickets of my professorship in multicultural education, autoethnography book publications, and journal editorship (Barnhardt et al., 2013). Although Dr. Wolcott never invited me to be part of his circle of editorial assistants, he unexpectedly mentored me to become a founding editor-in-chief for two journals of multicultural education, which have challenged discrimination and promoted educational equity for all.

My rollercoaster journey of journal editing began in 1997 when, after an 8year hiatus, I reentered academia as an assistant professor of multicultural education at Eastern University. Within a year of my appointment, my desire to journal-edit raised its head. I pulled together my creative energy to enter this arena of journal editing, not from the side door but from the front door. Instead of knocking at the doors of existing journals as an apprentice, I knocked at the door of Dr. Vivian Nix-Early, then Dean of the Graduate and Professional Studies at Eastern. This African-American woman leader heard my dream of beginning a new journal and did not doubt my ability. Instead, she tossed a new question back at me, "How about an online journal?" No funding was offered, but her acceptance of my idea itself was sufficient to fuel my desire to build something shareable with the global learning community. So was born an open-access journal. Looking back, I flinch at my scholarly and managerial naiveté when I launched EMME in 1999. I was a fledgling non-tenured assistant professor, initially without funding or a graduate assistant and with a full teaching load. So EMME was birthed on the ground of scarcity but has grown healthy on the backs and shoulders of many self-giving scholars from Eastern University and elsewhere, underpaid graduate students, Eastern's technology support, and my "sweat equity" of innumerable volunteer hours as its founding editor. Editing EMME taught me how to "become" a journal editor with few resources but a big vision.

My "becoming" story is not typical for academic journal editors, especially 20 years ago. I basically crossed all boundaries implicitly set by the scholarly community. If I had closely watched how Dr. Wolcott had operated as an effective journal editor, it is possible that I might have never started a journal on my own because I might have become more of a realist than an idealist. Typically, journal editors come out of a community of well-established scholars who are known to their academic community, have demonstrated respectable publishing records, and often are selected by their academic peers. For this reason, Brown's (2014) advice to early scholars makes sense. She emphasized that junior scholars should participate actively in academic production as authors, reviewers, and editorial 
board members instead of keeping their eyes on the prize of Editor-in-Chief. Perhaps the 2018 call for editors by the Academy of Management implies the same message, describing the qualifications of candidates as follows:

- Significant scholarly contributions in management, including publications associated with the mission of the journal.

- Extensive experience and an excellent reputation as a reviewer, an editorial board member, or an editor of a management-related journal. (Academy of Management, 2018) [italics added]

I did not have any of these qualifications. I was a yet-to-be-tenured junior faculty at the assistant professor rank with a publishing record of only one book and a few articles under my belt. I was even an English-as-a-second-language speaker. Above all, I did not have a budget to operate this new journal. Yet, I began a "platinum" open-access journal that did not charge an "article processing charge" to authors (a fee that an author pays to make his/her article available as an openaccess article for other users) as well as a subscription or user fee to readers (a fee that a user pays to access an article or a journal). Despite criticisms about the quality problem and predatory practices of some open-access journals (Beall, 2015), my sense of justice about knowledge distribution fit the open-access principles that access to good knowledge should not be restricted only to those with financial means or institutional support and that equitable access to good knowledge could make the world a better, more equitable, place. This is the essence of multicultural education as I have embraced it. I thank my Eastern University for having been behind the journals and me in our attempt to live the university's commitment to justice (Eastern University, n.d.)

Looking back at the early days, I wonder what inspired me to start a new journal from scratch without much knowledge, skill, and experience. It certainly came out of my audacity, naiveté, and ignorance. I believe that it also came out of the cultural context in which I was placed. As a marginalized female academic of color, who is a speaker of English as a second language, I might have subconsciously acted as a "tampered radical" who works with the establishment while attempting transformation from the margin (Hernandez, Ngunjiri, \& Chang, 2014). By defying the convention of closing the doors of prestige to newcomers who do not fit the academic standards, I was perhaps creating a new space where I could lead from the center despite my status as a newcomer and outsider. Like many immigrants who created their own paths along untraveled roads while settling in their new environments, I was perhaps challenging the deficiency-based mindset with my belief in strengths and sweat equity. Subscribing to Gonzalez, Moll, and Amanti's (2005) notion of "funds of knowledge," I was perhaps counting, in my funds of knowledge, my multicultural/multilingual knowledge and experience, belief in the power of education, and sensitivity about the duality of justice-privilege as an educated elite yet racial-ethnic-gender minority in the U.S. academy. I also wonder if my upbringing in a collectivistic society, with a Christian notion of grace and gifting without expecting returns, allowed me to envision radical generosity, in the form of the platinum open-access journal, as a viable possibility in the academy. So I began the experiment of creating a new global online journal, a platform where 
scholars, practitioners, and students of multicultural education from different parts of the world could freely share their theoretical and practical knowledge of multicultural education. Providing free access to knowledge seemed so fair and necessary in a world in which economic inequality and the hegemony of the established West continue to divide the world between the have's and the havenot's even in academia. I was encouraged by the many authors, reviewers, editors, advisors, and tech supporters of EMME and IJME who demonstrated that I was not alone in this experiment of radical generosity. They added their own sweat equity to these two journals. Some have remained as loyal friends and volunteers to EMME and IJME over the years. For example, Dr. Linda Stine, now a retired writing professor from Lincoln University, has single-handedly copyedited articles for almost 15 years. With the global community of hundreds of volunteers, I have continued my journey of "being" a journal editor.

\section{Being}

As I settled into this identity of journal editor, my skills and proficiency grew in journal editing, management, leadership, networking, communication, editorial collaboration, public relations, journal promotion, and marketing. My growth in these areas was absolutely necessary to maintain and grow the academic integrity and rigor of the journals. I realized that "being" a journal editor, however, was more than ascertaining the effective process and production of academic journal publishing. Rather, it meant carrying out three other critical roles as a conscientious guardian of the academic discipline, protector of organizational integrity, and steward to people in the community.

First, my journal editor identity includes being a conscientious guardian of the academic discipline of multicultural education. As the Editor-in-Chief of IJME, I have to make sure that articles submitted to and published by IJME represent this academic discipline appropriately and contribute to the advancement of the field. According to Banks and Banks (2015) and Sleeter and Grant (2007), the field of multicultural education emerged as an academic discipline in the 1960s in response to the Civil Rights Movement in the United States. The primary concern of multicultural education at the time was with racial and ethnic justice in relation to educational access and quality, particularly for minority students. Since then, multicultural education has expanded its scope of concerns to include multidimensions of diversity including race, ethnicity, indigeneity, immigration, language, disability, gender, sexual orientation, religion, and nationality at the global, national, regional, and school level (Bennett, 2010; Nieto \& Bode, 2018). Also, multicultural education is concerned about providing quality education to all students across multicultural divides while affirming diversity and embracing cultural differences. To scholars and practitioners, it is particularly important to achieve social justice through educational equity in local and global contexts (Gorski \& Pothini, 2018). To this end, Sleeter (2018) called for power sharing between the dominant majority and the underprivileged minority when making 
decisions to spread educational benefits for all. As I have involved myself in every stage of the editorial process from attracting and managing submissions to engaging reviewers, selecting high-quality submissions, and distributing articles, I am cognizant of the need to maintain the integrity of multicultural education as a maturing academic discipline. Therefore, I, along with other EMME-IJME editors, have declined some submissions, despite their high-quality scholarship or highprofile authorship, because they did not fit the multicultural education scope of the journal or would not sufficiently advance the existing discipline. With this sense of guardianship, I have also repeatedly revisited the boundaries of multicultural education as an academic discipline and guarded the existing boundaries while cautiously making room for new ideas, new authorship, and new readership to advance the discipline continuously.

Second, being a journal editor means protecting the journal's organizational identity. IJMEs logo publicly announces its identity as an equity-focused, openaccess, and peer-review journal. The equity focus, as discussed earlier, has been realized in two ways: by publishing multicultural education materials focusing on educational equity and justice and by providing global readers free access to the journal content. The first type of equity was already discussed above. The second type of equity commitment has been the driving reason to keep both EMME and IJME open for all these years. Since open-access publishing still needs financial support, we have adopted the combination of two sustainability models-securing institutional support and volunteer services by scholars. Beall (2015) also mentioned the third option of financing open-access publishing through passing the article processing charges to authors, which we have rejected. I am grateful for Eastern University and Yonsei University for helping me to maintain the openaccess commitment of both journals. In addition to protecting the equity-focus and open-access commitment, my responsibility has been ensuring a credible and rigorous peer review process. Peer reviews have been conducted by our volunteer reviewers from around the world. The IJME editorial board, of which I am a member, has engaged carefully selected reviewers, based on their expertise and review track record, to secure "timely, substantial, and constructive" reviews. Reflecting on my journal editor role as a protector of the organizational identity, I realize that the temptation of mission drift, away from this organizational identity of equityfocus, open-access, and peer-review, was always lurking, especially at times of financial and publishing deadline pressure.

Third, being a journal editor means, to me, being a conscientious steward, namely a caretaker, of people in the community. The people in the EMME-IJME community include authors, reviewers, editors, advisors, editorial assistants, and, above all, readers. My relationship with some was short-lived while other relationships lasted much longer. Some authors came to our door with a hope of finding a home for their hard-worked manuscripts but left with disappointment, whereas others ended up remaining as our published authors. Some reviewers, editors, and advisors rendered their service for a short time; others have repeated their volunteer services for many years. Some readers have stayed with us for all these years, while some joined our community more recently. Now our community of registered users has reached tens of thousands from over 200 countries. Other 
users, not registered with us but known to us through web analytics tools, have also been welcomed to our community as they read, cite, and recommend our articles. As a steward, I have kept IJME going so that the community continues to be nourished and the past efforts of our authors, reviewers, and editors do not get lost in the cyber world without a caretaker.

Over 20 years, I have tried to "be" the journal editor who leads with an intent to guard the field of multicultural education, protect the organizational mission of the journals, and serve as a steward to this community of people. I am generally satisfied with efforts I have made to keep the journals alive as open-access publications. However, I am not without regrets. I wish I had spent more time on some acceptance decisions; given more constructive editorial comments to some; invested more time in mentoring junior scholars and editors; better acknowledged the efforts of departing editors; written more gracious decline emails; and moved forward some review processes faster, to mention just a few. Above all, however, these 20 years of journal publishing have left me with a profound gratitude to many leaders and followers who have shaped these two journals and my journal editor identity. Although I cannot name them all in this essay, I am confident that they know who they are. Besides the late Dr. Wolcott who unintentionally planted a desire in me of becoming a journal editor and Dr. Nix-Early who said yes to my initial idea, I cannot give enough thanks to the many administrators and faculty members who have rendered their service and support to these low-income, but noble, open-access experiments; to some 20 editors, another 30+ advisors, hundreds of active reviewers; to thousands of authors; and to tens of thousands of readers. It is with satisfaction about what these two journals have accomplished and my profound gratitude to the entire IJME community, sprinkled with regrets about my shortcomings, that I am leaving my post as the Editor-in-Chief of IJME.

\section{Beyond}

My decision to depart has been made for organizational, missional, and personal reasons. Organizationally speaking, I have come to the realization that IJME has grown as much as the current infrastructure and its operational capacity can support. The journal has grown to the point at which a new infrastructure and leadership from a more scholarship- and resource-rich institutional environment would add more value to this maturing organization. This logic is well supported by the organizational life cycle framework (Hanks, 1990; Tam \& Gray, 2016). Therefore, with the support of the editorial board, I have come to a decision that IJME be released to a tier-one research institution that can support the scholarship of multicultural education and keep the commitment to engaging the global community. Missionally speaking, the journal has always been intended as an "international" journal that embraces the whole world. IJME has made many intentional efforts to involve the global community of scholars and practitioners in its circle of authors, reviewers, and editorial advisors. By moving its publishing headquarters to the Asian continent, IJME intends to tap into a new circle of 
scholars whom the journal has not yet fully embraced and a new scholarly framework beyond its founding nation, sponsoring institution, and established network of knowledge production. Finally, from a personal perspective, I plan to reprioritize my commitment to scholarship. Over the last 20 years, I have committed my time to helping others produce new knowledge and distributing it to global consumers of multicultural education. With the remaining years in my academic career, I feel called to participate more actively in my own production of new knowledge, particularly in the field of organizational leadership development, with the framework of justice, multiculturality, and self-reflexivity. These organizational, missional, and personal reasons, combined, have encouraged me to this shift in my identity-making. For the last three and a half years, IJME has been co-sponsored by Eastern University's PhD in Organizational Leadership program and Yonsei University's The Institute for Educational Research. By working with Yonsei faculty in and outside IJMEs editorial board, I, along with the Board, am convinced that the journal will continue to exist in a supportive and thriving environment.

I do wonder about my identity beyond my departure from IJME as its chief editor. I know that I will have to drop my title as IJME's Editor-in-Chief from my email signature line. Will the journal editor identity be erased from my identity profile in the same way as my Korean citizenship was wiped out when I became a citizen of a different country? Or will it be like my Korean-ness being retained in my self-identity make-up despite my official change of citizenship? Or will it be like my unchanged gender identity regardless of my citizenship? It is difficult to imagine that my journal editor identity of 20 years will simply disappear from my enduring identity composition. I know for sure that even without the journal editor title I will continue to benefit from editorial skills and knowledge gained from my editorial work. Therefore, this cultural competence and proficiency will endure in my future work. Although I realize that my newly shaped identity will be devoid of this professional title, my being will not be able to get rid of my lived experience as a journal editor in the same way that, while I am no longer a Korean citizen, I cannot get rid of my cultural and linguistic competence as a Korean or of my Korean-ness. As I have expanded my socio-cultural and legal identity as a US citizen and added, to my identity profile, German cultural and linguistic competence through my marital connection, I also realize that my Korean-ness is no longer the same as what existed before my tri-culturality began to take shape. My identity will continue to evolve into something different-no longer as IJMEs Editor-in-Chief but as its founder and friend.

What will also happen to the identity of IJME beyond our disentanglement of identities? IJME will retain its name and continue to grow as an academically rigorous journal, still rooted in collaboration among international scholars, practitioners, and students of multicultural education. IJME will continue to espouse its mission of "promoting educational equity for all" even as it sheds its association with me as its editor-in-chief and Eastern University as its sponsoring institution. The IJME community of authors, readers, editors, and reviewers will expand as the organization matures and reaches to other parts of the world. The publishing framework, style, and even scope may adjust to shifting trends of 
multicultural education and its sustainability model will be revisited. Despite all the changes, the name IJME, the very identity of the journal, will remain constant and send out the powerful message that the journal will continue to thrive in its new place and time.

\section{With Blessings to IJME Leaders and Followers}

I often sign my emails with my favorite wish, "With Blessings." Dr. Robert Nash, my academic collaborator and a significant contributor to the scholarship of religion and education, once remarked that he has never known any academic who signs emails with "blessings." As a scholar of religion, he might have picked up on its significance. Although I was initially surprised by his remark, I still sign my emails with blessings, now with more consciousness. I like this ending because it conveys some serious intentionality of my good wishes. So I am going to end this essay with blessings to the new leaders and followers of IJME.

As I discussed earlier, my departure from IJME as Editor-in-Chief will reconfigure both my identity and IJMEs identity. I have already argued that such an identity evolution is a natural phenomenon from both an individual and an organizational perspective. However, organizational growth and success do not automatically follow leadership changes and the enhancement of environments. Rather, the new leaders and followers of the organization will have to work intentionally toward this goal of growth and success. I am fully convinced that IJME will be under capable and dedicated hands with the new Editor-in-Chief, Dr. SoonYong Pak at Yonsei University, and with its editorial board, editorial advisors, and reviewers. I am convinced that IJME will continue to attract high-quality submissions from committed authors and continue to make an impact on the field of multicultural education globally. Now, I want to leave with confidence that our readers will continue to honor the sacred practice of sharing knowledge with integrity and trust by giving due credit to its producers. With this community practice of applying new knowledge, produced and shared generously by our authors, to our work, we can bring more equitable education to all in the world, including those who have been previously precluded from educational opportunities.

With my profound appreciation of all having contributed to the existence and thriving of two journals, I now send IJME on a new voyage. I am glad that you all-authors, reviewers, editors and readers—are still part of the journey forward!

With blessings, Heewon 


\section{Acknowledgment}

I would like to thank my intellectual colleagues, Dr. Linda Stine, Dr. Heidi Lee, Dr. Sung won Kim, and Ms. Hannah Volpert-Esmond, for having carefully read my draft and provided helpful feedback.

\section{References}

Academy of Management. (2018). Call for nominations for academy of management editors. Retrieved from https://aom.org/uploadedFiles/ Publications/Call_for_nominees_for_editor_of_AMJ_or_Annals\%20.pdf

Adams. T., \& Jones, S. H. (2014). Autoethnography. Oxford, England: Oxford University Press.

Anderson, L. (2006). Analytic autoethnography. Journal of Contemporary Ethnography, 35(4), 373 - 395. doi:10.1177/0891241605280449

Banks, J. A., \& McGee Banks, C. A. (2015). Multicultural education: Issues and perspectives ( $9^{\text {th }}$ ed.). Hoboken, NJ: Wiley.

Barnhardt, R., Campbell, J., Chang, H., Harrison, B., Lincoln, L., \& McCarty, T.... (2013). In memoriam: Harry F. Wolcott, 1929-2012. Anthropology and Education Quarterly, 44(2), 211-212.

Beall, J. (2015). What the open-access movement doesn't want you to know. Retrieved from https://www.aaup.org/article/what-open-access-movementdoesn\%E2\%80\%99t-want-you-know\#.W7-ppNhKi9Y

Bennett, C. J. (2010). Comprehensive multicultural education: Theory and practice ( $7^{\text {th }}$ ed.). New York, NY: Pearson.

Brown, V. J. (2014). From early career researcher to editor-in-chief in 5 steps: How your contributions as an author and reviewer are important milestones on your path to success. Retrieved from https://www.elsevier.com/authorsupdate/story/career-tips-and-advice/from-early-career-researcher-toeditor-in-chief-in-5-steps

Chang, H. (1992). Adolescent life and ethos: An ethnography of a US high school. New York, NY: Falmer.

Chang, H. (2008). Autoethnography as method. New York, NY: Routledge.

Chang, H., Longman, K. A., \& Franco, M. A. (2014). Leadership development through mentoring in higher education: A collaborative autoethnography of leaders of color, Mentoring \& Tutoring: Partnership in Learning. 22(4), 373389. 
Chang, H., Ngunjiri, F., \& Hernandez, K. (2013). Collaborative autoethnography. New York, NY: Routledge.

Crenshaw, K. (1991). Mapping the margins: Intersectionality, identity politics, and violence against women of color. Stanford Law Review, 43(6), 1241-1299.

Denzin, N. K. (2006). Analytic autoethnography, or déjà vu all over again. Journal of Contemporary Ethnography, 35(4), 419-428.

Dervin, F., \& Jackson, J. (2018). Language, identity, and interculturality. In J. Jackson (Ed.), Interculturality in international education (pp. 63-81). New York, NY: Routledge.

Dugger, K. (1988). Social location and gender-role attitudes: A comparison of Black and White women. Gender and Society, 2(4), 425-448. doi:10.1177/089124388002004002

Eastern University (n.d.). Retrieved from https://www.eastern.edu/about-easternuniversity

Ellis, C. (2003). The ethnographic I: A methodological novel about autoethnography. Walnut Creek, CA: AltaMira.

Ellis, C., \& Bochner, A. P. (1996). Composing ethnography: Alternative forms of qualitative writing. Walnut Creek, CA: AltaMira.

Gonzalez, N., Moll, L. C., \& Amanti, C. (2005), Funds of knowledge: Theorizing practices in households, communities, and classrooms. New York, NY: Routledge.

Gorski, P. C., \& Pothini, S. G. (2018). Case studies on diversity and social justice education $\left(2^{\text {nd }}\right.$ ed.). New York, NY: Routledge.

Hanks, S. H. (1990). The organization life cycle: Integrating content and process. Journal of Small Business Strategy. 1(1): 1-12.

Hayano, D. (1979). Auto-ethnography: Paradigms, problems, and prospects. Human Organization, 38(1), 99-104.

Hernandez, K. C., \& Murray-Johnson, K. K. (2015). Towards a different construction of blackness: Black immigrant scholars on racial identity development in the United States. International Journal of Multicultural Education, 17(2), 53-72. doi: 10.18251/ijme.v17i2.1050.

Hernandez, K. C., Ngunjiri, F. W., \& Chang, H. (2015). Exploiting the margins in higher education: A collaborative autoethnography of three foreign-born female faculty of color. International Journal of Qualitative Studies in Education, 28(5), 533-551.

Hunt, S. A., \& Junco, N. R. (2006). Introduction to two thematic issues defective memory and analytical autoethnography. Journal of Contemporary Ethnography, 35(4), 371 - 392. doi: 10.1177/0891241606291617

Hughes, S. A., \& Pennington, J. L. (2016). Autoethnography: Process, product, and possibility for critical social research. Thousand Oaks, CA: Sage. 
International Journal of Multicultural Education. (n.d.). Retrieved from http://ijmejournal.org/index.php/ijme/index

Jenkins, R. (2014). Social identity (key ideas) (4th ed.). New York, NY: Routledge.

Jones, S. H., Adams, T., \& Ellis, C. (2013). Handbook of autoethnography. New York, NY: Routledge.

Jones, S. R., Kim, Y. C., \& Skendall, K. C. (2012). (Re-) framing authenticity: Considering multiple social identities using autoethnographic and intersectional approaches. The Journal of Higher Education, 83(5), 698-724. doi: 10.1080/00221546.2012.11777263

Kim, J., Lee, J., \& Lee, S. (2005). Understanding education fever in Korea. KEDI Journal of Educational Policy, 2(1), 7-15.

Litosseliti, L. (2006). Gender and language theory and practice. New York, NY: Routledge.

McClellan, P. (2012), Race, gender, and leadership identity: An autoethnography of reconciliation, International Journal of Qualitative Studies in Education, 25(1), 89-100. doi:10.1080/09518398.2011.647720

Marx, S., Pennington, J. L., \& Chang, H. (2017). Critical autoethnography in pursuit of educational equity: Introduction to the IJME special issue. International Journal of Multicultural Education, 19(1), 1-6. Retrieved from http://ijme-journal.org/index. php/ijme/article/view/1393

Mayer, C., \& May, M., (2018). Of being a container through role definitions: Voices from women leaders in organizational autoethnography. Journal of Organizational Ethnography, 7(3), 373387. doi:10.1108/JOE-10-2017-0052

Nash, R. J. (2004). Liberating scholarly writing: The power of personal narrative. New York, NY: Teachers College Press.

National Association of Multicultural Education (n.d.). Definitions of multicultural education. Retrieved from https://www.nameorg.org/definitions_of_ multicultural_e.php

Nesdale, D. (2017). Children and social groups: A social identity approach. In A. Rutland, D. Nesdale, \& C. S. Brown (Eds.), The Wiley handbook of group processes in children and adolescents (pp. 3-22). Hoboken, NJ: Wiley-Blackwell.

Nieto, S., \& Bode, P. (2018). Affirming diversity: The sociopolitical context of multicultural education (7th ed.). New York, NY: Pearson.

Ngunjiri, F. W., Hernandez, K., \& Chang, H. (2010). Living autoethnography: Connecting life and research. Journal of Research Practice, 6(1), Article E1. Retrieved from http://jrp.icaap.org/index.php/jrp/article/view/241/186

Qualitative Health Research (2016). Retrieved from http://journals.sagepub.com/toc/qhra/26/4 
Reed-Danahay, D. (1997). Auto/ethnography: Rewriting the self and the social. Oxford, England: Berg Publishers.

Sambrook, S., \& Herrmann, A. F. (2018). Organisational autoethnography: Possibilities, politics and pitfalls. Journal of Organizational Ethnography, 7(3), 222-234. doi: 10.1108/JOE-10-2018-075

Sleeter, C. E. (2018). Multicultural education past, present, and future: Struggles for dialog and power-sharing. International Journal of Multicultural Education, 20(1), 5-20. doi:10.18251/ijme.v20i1.1663

Sleeter, C. E., \& Grant, C. A. (2007). Making choices for multicultural education: Five approaches to race, class and gender ( $6^{\text {th }}$ ed.). Hoboken, NJ: Wiley.

Sorenson, C. W, (1994). Success and education in South Korea. Comparative Education Review, 38(1), 10-35.

Tam, S., \& Gray, D. E. (2016). Organisational learning and the organisational life cycle. European Journal of Training and Development, 40(1), 2-20. doi:10.1108/ejtd-07-2015-0052.

Walford, G. (2004). Finding the limits: Autoethnography and being an Oxford University Proctor. Qualitative Research, 4(3), 403-417. doi: 10.1177/1468794104047238

Way, N., \& Rogers, O. (2015). "[T] hey say Black men won't make it, but I know I'm gonna make it": Ethnic and racial identity development in the context of cultural stereotypes. In K. C. McLean \& M. Syed (Eds.). The Oxford handbook of identity development (pp. 269-285). Oxford, England: Oxford University Press.

Wolcott, H. F. (2002). Sneaky kid and its aftermath: Ethics and intimacy in fieldwork. Walnut Creek, CA: AltaMira.

Wolcott, H. F. (2004). The ethnographic autobiography. Auto/Biography, 12, 93106.

Yarborough, J. P., \& Lowe, K. B. (2007). Unlocking foreclosed beliefs: An autoethnographic story about a family business leadership dilemma. Culture and Organization, 13(3), 239-249.

Yoo, Y. (2012). Chakhan mokja: The life and mission of James S. Gale: Volume 2 [In Korean]. Seoul, Republic of Korea: Jinhung Publisher.

Yoon, E., Adams, K., Clawson, A., Chang, H., Surya, S, \& Jeremie-Brink, G. (2017). East Asian adolescents' ethnic identity development and cultural integration: A qualitative investigation. Journal of Counseling Psychology, 64(1), 65-79. doi: $10.1037 /$ cou0000181 


\section{Author Contact}

Heewon Chang: hchang@eastern.edu

Eastern University, College of Business and Leadership, PhD in Organizational Leadership, 1300 Eagle Road, St. Davids, PA 19087, USA 